\title{
Land, Innovation, and Social Good
}

\author{
Kwabena Obeng Asiama ${ }^{1, *} \mathbb{C}$, Rohan Bennett ${ }^{2,3}$, Christiaan Lemmen ${ }^{3,4} \mathbb{D}$ and Winrich Voss ${ }^{1}$ \\ 1 Geodetic Institute, Faculty of Civil Engineering and Geodetic Science, Leibniz University of Hannover, \\ 30167 Hannover, Germany; voss@gih.uni-hannover.de \\ 2 Swinburne Business School, Swinburne University of Technology, Hawthorn, VIC 3122, Australia; \\ rohanbennett@swin.edu.au \\ 3 Kadaster International, Cadastre, Land Registry and Mapping Agency of the Netherlands, \\ 7311 KZ Apeldoorn, The Netherlands; chrit.lemmen@kadaster.nl \\ 4 ITC Faculty, University of Twente, 7500 AE Enschede, The Netherlands; c.h.j.lemmen@utwente.nl \\ * Correspondence: asiama@gih.uni-hannover.de or kwabena.asiama@gmail.com; Tel.: +49-(0)-511-762-2406
}

Citation: Asiama, K.O.; Bennett, R.; Lemmen, C.; Voss, W. Land,

Innovation, and Social Good. Land 2021, 10, 503. https://doi.org/ 10.3390/land10050503

Received: 3 April 2021

Accepted: 30 April 2021

Published: 8 May 2021

Publisher's Note: MDPI stays neutral with regard to jurisdictional claims in published maps and institutional affiliations.

Copyright: (c) 2021 by the authors. Licensee MDPI, Basel, Switzerland. This article is an open access article distributed under the terms and conditions of the Creative Commons Attribution (CC BY) license (https:// creativecommons.org/licenses/by/ $4.0 /)$.
The administration of land tenure, value, and use is undergoing a new wave of technological innovation. The need for faster, more affordable, accessible, fit for purpose approaches to undertaking land administration functions has led to the push of applicable technological innovations into the arena. The maturation and scaled implementation of crowdsourced data capture techniques (i.e., ubiquitous mobile devices), imagery-based mapping approaches (i.e., HRSI, UAVs, LiDAR), and cloud storage options are all adding to the expanded land administration toolbox. Further from these developments, there is a mix of even more novel developments that are being advanced, including blockchain technology, smart contracts, computer-assisted land use planning decision support systems for smart cities, and automatic valuation models.

Running in parallel to these technological advances in the land administration domain are global-level societal challenges. These manifest as key livelihood problems within national borders and at the community level-and include issues of land rights inequality, slum formation, food insecurity, natural disaster risk, and exposure. These societal challenges are not new, but have been exacerbated in the past two decades: More people are increasingly exposed to the risks, most of the time, in more places. However, as with all social issues, societal challenges are rooted in their respective legal, social, and cultural peculiar contexts. Hence, attempts to resolve these challenges are also context specific. This notwithstanding, land issues are very appropriate to create social innovation, based on technological evolutions and combined with civic society activities. The papers presented in this Special Issue further contribute to social innovations via the improvement in land administration processes.

The relationship between the two issues, technological innovations and societal challenges, which are related to the administration of land in this Special Issue, form two theories about the sources of innovation. On the one hand, the aspect of technological innovation, which makes science and technology the central theme-the driver of innovation-and highlights its roles in the development of solutions to societal challenges. This has been described by many as a 'supply side' motivation for innovation or more commonly 'technological push'. On the other hand, the pull of the societal demands, where innovation is defined by the conditions or needs of the recipient community of users. Here, there is recognition of the demands of the community within a broader socio-political context, and more importantly characteristics of the end market, especially the end users, as well as the total makeup of the community, including the social, economic, legal, and political characteristics, are all considered important.

Therefore, the focus of this Special Issue lies at the nexus of the exploration of this interaction between technological innovation and social challenges, in the context of land administration. The Special Issue aims at providing an overview of the trending developments in the technologies aiding the functions of land administration, the societal demands 
that drive the developments or the applications of these technologies, and how these forces interact in terms of designed systems, impacts, and outcomes. The Special Issue, in terms of the trending technological developments in the sphere of land administration, on the one hand, presents articles relating to current developments and better implementation of currently used technologies-GNSS, and smartphone apps, for example-as well as the modelling of workflows to support these technologies-such as process modelling, cadastral evaluation services, and participatory land administration. On the other hand, the Special Issue presents a retinue of the societal demands that necessitate the adoption of the technologies and techniques indicated. These societal demands include gender equality, land tenure security, environmental protection, food security, and sustainable cities and settlements (Figure 1).
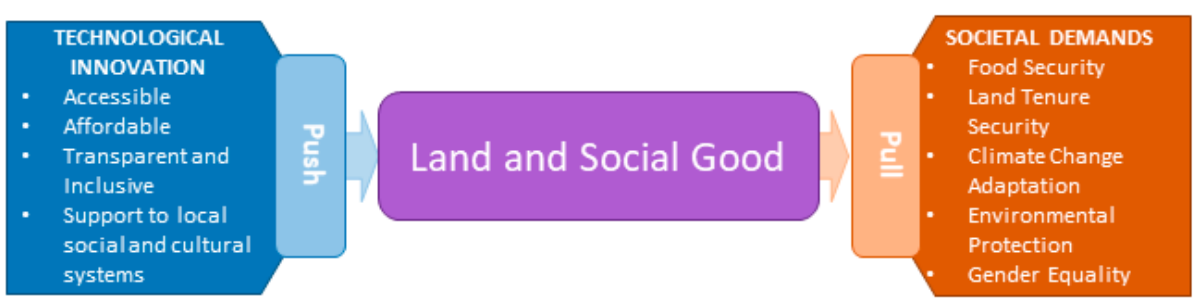

Figure 1. The aspects of land, innovation, and social good.

The collection of peer-reviewed articles in the Special Issue number thirteen, include nine research articles, three review articles, and one project report. These articles were developed by multidisciplinary teams, drawn from Africa, Asia, Oceania, North America, and Europe, with a consequential spread in the geographical focus of these studies across the same areas, summarised in Table 1 below.

Table 1. Overview of the papers presented in the Special Issue.

\begin{tabular}{|c|c|c|c|c|}
\hline Source & Title & $\begin{array}{c}\text { Country/Geographic } \\
\text { Context }\end{array}$ & $\begin{array}{c}\text { Technological Innovation } \\
\text { and Techniques }\end{array}$ & $\begin{array}{l}\text { Societal } \\
\text { Demand }\end{array}$ \\
\hline Aditya et al. & $\begin{array}{c}\text { Participatory Land } \\
\text { Administration in Indonesia: } \\
\text { Quality and Usability } \\
\text { Assessment }\end{array}$ & Indonesia & $\begin{array}{l}\text { Participatory Land } \\
\text { Registration, GNSS }\end{array}$ & $\begin{array}{l}\text { Land Tenure } \\
\text { Security }\end{array}$ \\
\hline Ameyaw et. al. & $\begin{array}{c}\text { Transparency of Land } \\
\text { Administration and the Role of } \\
\text { Blockchain Technology, a } \\
\text { Four-Dimensional Framework } \\
\text { Analysis from the Ghanaian } \\
\text { Land Perspective }\end{array}$ & Ghana & Blockchain Technology & $\begin{array}{l}\text { Land Tenure } \\
\text { Security }\end{array}$ \\
\hline Asiama et al. & $\begin{array}{c}\text { Towards Responsible } \\
\text { Consolidation of Customary } \\
\text { Lands: A Research Synthesis }\end{array}$ & Ghana & Smartphone Apps & $\begin{array}{l}\text { Food Security, } \\
\text { Land Tenure } \\
\text { Security }\end{array}$ \\
\hline $\begin{array}{l}\text { Auziňr, } \\
\text { Armands }\end{array}$ & $\begin{array}{l}\text { Capitalising on the European } \\
\text { Research Outcome for Improved } \\
\text { Spatial Planning Practices and } \\
\text { Territorial Governance }\end{array}$ & Europe & - & $\begin{array}{l}\text { Sustainable } \\
\text { Cities and } \\
\text { Settlements }\end{array}$ \\
\hline Bennett et al. & $\begin{array}{l}\text { Hybrid Approaches for Smart } \\
\text { Contracts in Land } \\
\text { Administration: Lessons from } \\
\text { Three Blockchain } \\
\text { Proofs-of-Concept }\end{array}$ & $\begin{array}{l}\text { Australia (New South } \\
\text { Wales)SwedenCanada } \\
\text { (British Columbia) }\end{array}$ & $\begin{array}{c}\text { Smart Contracts, } \\
\text { Blockchain Technology }\end{array}$ & $\begin{array}{l}\text { Land Tenure } \\
\text { Security }\end{array}$ \\
\hline Choei et al. & $\begin{array}{l}\text { Improving Infrastructure } \\
\text { Installation Planning Processes } \\
\text { using Process Modelling }\end{array}$ & South Korea & $\begin{array}{l}\text { Infrastructure Installation } \\
\text { Planning, Process Modelling }\end{array}$ & $\begin{array}{l}\text { Sustainable } \\
\text { Cities and } \\
\text { Settlements }\end{array}$ \\
\hline
\end{tabular}


Table 1. Cont.

\begin{tabular}{|c|c|c|c|c|}
\hline Source & Title & $\begin{array}{c}\text { Country/Geographic } \\
\text { Context }\end{array}$ & $\begin{array}{l}\text { Technological Innovation } \\
\text { and Techniques }\end{array}$ & $\begin{array}{l}\text { Societal } \\
\text { Demand }\end{array}$ \\
\hline Deng et al. & $\begin{array}{l}\text { Land Registration, Adjustment } \\
\text { Experience, and Agricultural } \\
\text { Machinery Adoption: Empirical } \\
\text { Analysis from Rural China }\end{array}$ & China & - & $\begin{array}{l}\text { Food security, } \\
\text { Land Tenure } \\
\text { Security }\end{array}$ \\
\hline Home et al. & $\begin{array}{l}\text { History and Prospects for } \\
\text { African Land Governance: } \\
\text { Institutions, Technology, and } \\
\text { 'Land Rights for All' }\end{array}$ & Africa & - & - \\
\hline $\begin{array}{l}\text { Ntihinyurwa } \\
\text { et al. }\end{array}$ & $\begin{array}{l}\text { Farmland Fragmentation, } \\
\text { Farmland Consolidation and } \\
\text { Food Security: Relationships, } \\
\text { Research Lapses and } \\
\text { Future Perspectives }\end{array}$ & - & - & Food Security \\
\hline Paradza et al. & $\begin{array}{l}\text { Could Mapping Initiatives } \\
\text { Catalyze the Interpretation of } \\
\text { Customary Land Rights in Ways } \\
\text { that Secure Women's } \\
\text { Land Rights? }\end{array}$ & Sub-Saharan Africa & - & $\begin{array}{l}\text { Gender } \\
\text { Equality }\end{array}$ \\
\hline Salifu et al. & $\begin{array}{c}\text { Innovating Along the } \\
\text { Continuum of Land Rights } \\
\text { Recognition: Meridia's } \\
\text { 'Documentation Packages' } \\
\text { for Ghana }\end{array}$ & Ghana & $\begin{array}{l}\text { Evaluation of Meridia Land } \\
\text { Documentation }\end{array}$ & $\begin{array}{l}\text { Land Tenure } \\
\text { Security }\end{array}$ \\
\hline Sousa et al. & $\begin{array}{l}\text { Evaluation of the Objectives and } \\
\text { Concerns of Farmers to Apply } \\
\text { Different Agricultural } \\
\text { Managements in Olive Groves: } \\
\text { The Case of Estepa Region } \\
\text { (Southern, Spain) }\end{array}$ & Southern Spain & - & $\begin{array}{l}\text { Environmental } \\
\text { Protection, } \\
\text { Food Security }\end{array}$ \\
\hline Trystuła et al. & $\begin{array}{c}\text { Evaluation of the Completeness } \\
\text { of Spatial Data Infrastructure in } \\
\text { the Context of Cadastral } \\
\text { Data Sharing }\end{array}$ & Eastern Poland & $\begin{array}{c}\text { Evaluation of local cadastral } \\
\text { network services }\end{array}$ & $\begin{array}{l}\text { Land Tenure } \\
\text { Security }\end{array}$ \\
\hline Twum et al. & $\begin{array}{l}\text { Gender, Land and Food Access } \\
\text { in Ghana's Suburban Cities: A } \\
\text { Case of the Adenta Municipality }\end{array}$ & Ghana & - & $\begin{array}{l}\text { Food Security, } \\
\text { Land Tenure } \\
\text { Security, } \\
\text { Gender } \\
\text { Equality }\end{array}$ \\
\hline
\end{tabular}

This following presents the works that make up the Special Issue. The above table shows the spread in the focus of the papers in this Special Issue, with a number of the papers focussing on either technological innovation, societal demands or both. The papers in the issue are presented below in the alphabetical order of the authors' last names. This is deemed a straight forward and equitable way of arranging the equally weighted articles: All contribute meaningfully and directly to the overarching theme of the Special Issue.

Aditya et al. [1] present a project report on a quality and usability analysis of participatory land registration (PaLaR) in the rural areas of Indonesia, focusing on data quality, cost, and time. PaLaR is described by the authors as a community-focused systematic land titling project that is aimed at collecting spatial and legal data. The work, based on a pilot study comparing PaLaR and the regular systematic land registration, in terms of their spatial accuracy, conducted in two rural communities, finds that though PaLaR resulted 
in a lower spatial accuracy, it was a better fit locally, providing the needed spatial and legal information.

Ameyaw and de Vries [2] add on the growing arena of blockchain technology, and its application to land administration. Drawing on the Ghanaian perspective, the authors review the potentials of using blockchain technology to enhance the transparency of land administration functions. The authors, after an examination of the land tenure registration, valuation, use planning processes, find that it is possible to have a permissionless public blockchain across all the processes of land administration. This integration of the land administration processes, responsible departments, and stakeholders, thus could foster openness, availability, access to information, and promote transparency and participation in the land administration processes. However, the authors are quick to point out the possible threats and pitfalls - such as limited storage of data and scalability, and the electricity consumption needed for the operations.

With the limited use of land consolidation, and a decreasing level of food security in the Sub-Saharan African (SSA) region, Asiama et al. [3] synthesize four studies that describe the development of a responsible land consolidation strategy, with one fit for the region. In this paper, the authors show the comparison of three countries with a responsible land consolidation strategy to one without. This is done to determine the factors that inhibit the development of a responsible land consolidation strategy. Further studies in the synthesis describe the development of the participatory land administration, as well as a land valuation approach and a land reallocation approach to address the factors inhibiting the use of land consolidation on SSA's customary lands, respectively. Though the synthesis concludes that the developed land consolidation strategy will reduce land fragmentation towards increasing food productivity, local customs in the area can be an impediment.

Auziňš Auziňš [4] distinguishes between planning systems and practices, with the aim of determining the pre-conditions and the challenges that need to be considered to improve spatial and development practice in the future. The author explores the trends and directions in the evolution of spatial and territorial governance, with a focus on the connections between the EU policies and the diverse national planning perspectives. The key results from a literature review and a comparative study were that, firstly, there is the need for an agenda-setting for comprehensive evidence gathering (CEG) if exploring spatial planning practices and territorial governance in selected European countries, and secondly, that a set of objectives for a values-led planning (VLP) approach needs to be introduced for improvement of land use management.

Bennett et al. [5] further explore the implications on the use of blockchain technologies on the functions of land administration, with a specific focus on smart contracts. With three proof of concept cases from Sweden, Australia (New South Wales), and Canada (British Columbia), the authors examine the hybrid approaches being used to introduce smart contracts into the current land registration technology infrastructure, in order to keep the land registry as the ultimate decider of the validity of transactions. The results from the comparison shows that the hybrid approach can enable the adherence to land administration business requirements, with further scaling implementation requiring a more holistic view of the sector, with attention being given to the remaining issues, that among others, include business model analysis, stakeholder acceptance, and trust building.

Choei et al. [6] present an analysis of the time and costs constrained in implementing a development impact fee (DIF) in South Korea. In this study, the authors use a case study in Jeju South Korea to compare the efficacy of a proposed approach, procedural modelling method using CityEngine, to the traditional method which uses AutoCAD. The study finds that that procedural modelling provides real-time 2- and 3-dimensional modelling and design evaluation. Moreover, it allows for a more efficient assessment of plan quality and calculation of DIF and further uncovers the need to diffuse procedural modelling to better support local planning practices.

Deng et al. [7] link land tenure security to advance factor inputs in agricultural modernisation in developing countries, with an aim of clarifying their relationships from 
the perspective of property rights theory and endowment effects. The study finds that though land registration does not have an effect on the rate of farm machinery adoption, and a negative experience in adjusting to new technologies exists, the interaction between land registration and adjustment experience has a positive impact on the adoption of agricultural machinery.

Providing a bird-eye view of the past, and present situation of African land governance, as well as proffering suggestions for the future direction, the communication article provided by Home [8] explores, through a multi-disciplinary approach, the recent advances in geo-spatial technology on the African continent. Zooming down to four Anglophone countries in the region, the article draws upon a range of sources to discuss how among other things, the colonial legacies of these countries have influenced the culture of their national land administration systems.

Ntihinyurwa and de Vries [9] in this review article interrogate the relationship between farmland fragmentation and farmland consolidation, and the variations of food security, to develop a model that will indicate the conditions under which farmland fragmentation needs to be maintained, resolved or controlled for the purposes of food security. The study finds that whilst the best management of farmland fragmentation for food security purposes can be achieved by minimizing the problems associated with physical and tenure aspects of farmland fragmentation along with the optimization of its potential benefits, various agriculture intensification programs, agroecogical approaches, and land saving technologies can be the most suitable strategies to maximize the income from agriculture on fragmented plots under the circumstances of beneficial fragmentation.

The initiatives towards securing the land tenure rights of womenin Sub-Saharan Africa's customary lands are often undermined by among others, inadequate community awareness and the challenges of recording the land rights. Paradza et al. [10] analyze case studies of selected mapping initiatives in SSA to determine the extent to which mapping both as a cadastral exercise and emerging practice in the initiation of participatory land governance initiatives, catalyze the transmission of customary land rights in ways that have a positive impact on women's access to land in customary land tenure areas. The study finds that some of the bottlenecks of these initiatives include the expensive softand hardware, illiteracy of women, legal status of the maps in the community, and in the country, among others. This work makes a significant contribution to our understanding of what instruments in the land registration toolbox can strenthen women's land rights.

Salifu et al. [11] explore how the land Documnetation Packages from Meridia recognises the continuum of land rights in its innovative land registration processes within the institutinal setting of Ghana. The authors describe the processes of registration, as well as the actors involved and the nature of their encounters, both in terms of the conventional registration process and that of Meridia. The study finds that though Meridia's process reflects the continuum of land rights, it also poses questions for future research regarding the political economy of land tenure certification and regarding the actual uses and benefits of issued certificates.

Sousa et al. [12] investigate the drivers and concerns that condition farmer's choices of a given olive groove management model. In a case study in the Estepa region of Spain, the authors find that most of the concerns of the olive farmers were directed towards conservation objectives. It was further found that organic and educated olive farmers are more likely to share this view.

Trystuła et al. [13] assess the completeness of National Spatial Data Infrastructures (NSDIs) containing the core land administrationd dataset-the cadastral dataset- also a key part of the EU's INSPIRE project. The authors develop an assessment framework which enables the identification of websites that publish cadastral data through INSPIRE network services, and those with a high development potential. The authors recommend the results of the assessment to be used in the ongoing construction of NSDIs and to improve the quality of network services and their availability for end users. 
Twum et al. [14] explore the underlying gender disparity in the access to food and land in the suburban cities of Ghana, and its evolution through the years as a result of settlement expansion and urban growth. Using a case study in the Adneta Municipality of Ghana, the authors find that though women engage with the power structures on a daily basis, the result is either a burden, a benefit or both, depending on their socio-cultural status and other factors in terms of access to food and land.

Overall, this Special Issue brings together a wide range of landed societal demands and attempts to meet them using contemporary technology innovations. It shows a deepening recognition of, and need to explore, the societal demands of food security, land tenure security, sustainable cities and communities, and environmental protection, in the context of land administration. Morover, technologies such as blockchain technology, smartphone apps, and GNSS are also shown to assist in dealing with such societal demands, albeit each bringing its own flow-on challenges, and potentially unintended consequences. The collection also brings to the fore, the need to have the views of the local people, users, and stakeholders taken into account during the design and ongoing upkeep of land administration systems.

Author Contributions: Conceptualization and writing—original draft preparation, K.O.A.; writingreview and editing, R.B., C.L. and W.V. All authors have read and agreed to the published version of the manuscript.

Funding: This research received no external funding.

Acknowledgments: The authors acknowledge the support of colleagues and peers from their affiliated institutions and those working more broadly in the land administration domain.

Conflicts of Interest: The authors declare no conflict of interest.

\section{References}

1. Aditya, T.; Maria-Unger, E.; Bennett, R.M.; Saers, P.; Lukman Syahid, H.; Erwan, D.; Wits, T.; Widjajanti, N.; Budi Santosa, P.; Atunggal, D.; et al. Participatory Land Administration in Indonesia: Quality and Usability Assessment. Land $2020,9,79$. [CrossRef]

2. Ameyaw, P.D.; de Vries, W.T. Transparency of Land Administration and the Role of Blockchain Technology, a Four-Dimensional Framework Analysis from the Ghanaian Land Perspective. Land 2020, 9, 491. [CrossRef]

3. Asiama, K.O.; Bennett, R.; Zevenbergen, J. Towards Responsible Consolidation of Customary Lands: A Research Synthesis. Land 2019, 8, 161. [CrossRef]

4. Auziňš, A. Capitalising on the European Research Outcome for Improved Spatial Planning Practices and Territorial Governance. Land 2019, 8, 163. [CrossRef]

5. Bennett, R.M.; Miller, T.; Pickering, M.; Kara, A.-K. Hybrid Approaches for Smart Contracts in Land Administration: Lessons from Three Blockchain Proofs-of-Concept. Land 2021, 10, 220. [CrossRef]

6. Choei, N.-Y.; Kim, H.; Kim, S. Improving Infrastructure Installation Planning Processes using Procedural Modeling. Land 2020, 9, 48. [CrossRef]

7. Deng, X.; Yan, Z.; Xu, D.; Qi, Y. Land Registration, Adjustment Experience, and Agricultural Machinery Adoption: Empirical Analysis from Rural China. Land 2020, 9, 89. [CrossRef]

8. Home, R. History and Prospects for African Land Governance: Institutions, Technology and 'Land Rights for All'. Land 2021, 10, 292. [CrossRef]

9. Ntihinyurwa, P.D.; de Vries, W.T. Farmland Fragmentation, Farmland Consolidation and Food Security: Relationships, Research Lapses and Future Perspectives. Land 2021, 10, 129. [CrossRef]

10. Paradza, G.; Mokwena, L.; Musakwa, W. Could Mapping Initiatives Catalyze the Interpretation of Customary Land Rights in Ways that Secure Women's Land Rights? Land 2020, 9, 344. [CrossRef]

11. Salifu, F.; Abubakari, Z.; Richter, C. Innovating Along the Continuum of Land Rights Recognition: Meridia's “Documentation Packages" for Ghana. Land 2019, 8, 189. [CrossRef]

12. Rodríguez Sousa, A.A.; Parra-López, C.; Sayadi-Gmada, S.; Barandica, J.M.; Rescia, A.J. Evaluation of the Objectives and Concerns of Farmers to Apply Different Agricultural Managements in Olive Groves: The Case of Estepa Region (Southern, Spain). Land 2020, 9, 366. [CrossRef]

13. Trystuła, A.; Dudzińska, M.; Źróbek, R. Evaluation of the Completeness of Spatial Data Infrastructure in the Context of Cadastral Data Sharing. Land 2020, 9, 272. [CrossRef]

14. Twum, K.O.; Asiama, K.; Ayer, J.; Asante, C.Y. Gender, land and food access in ghana's suburban cities: A case of the adenta municipality. Land 2020, 9, 427. [CrossRef] 